\title{
Ocena poziomu hałasu wewnątrz tramwajów na podstawie badań
}

\begin{abstract}
W artykule przedstawiono wyniki pomiarów hałasu wewnqtrz wybranych tramwajów eksploatowanych $w$ MPK Poznań. Pomiary przeprowadzono na postoju oraz w czasie jazdy na wybranych odcinkach torów podczas normalnego wykonywanego zadania transportowego. Otrzymane wyniki skonfrontowano z obowiqzujacymi normami i przepisami w zakresie dopuszczalnego poziomu hałasu w pojazdach i na stanowiskach pracy.
\end{abstract}

\section{Wstęp}

Hałas jest zjawiskiem niepożądanym w codziennym życiu człowieka. Powoduje zakłócenie aktywności (wypoczynku, komunikacji słownej, pracy umysłowej itp.), stwarzając odczucie dyskomfortu i uciążliwości. Hałas wpływa niekorzystnie na narząd słuchu, układ nerwowy i krążenia oraz inne narządy wewnętrzne. Spośród wielu, najbardziej trafną jest definicja podana w [1]: „hałasem są wszelkie niepożądane, nieprzyjemne, dokuczliwe lub szkodliwe drgania mechaniczne ośrodka sprężystego, działające za pośrednictwem powietrza na organ słuchu i inne zmysły oraz elementy organizmu człowieka". $Z$ definicji tej wynikają dwa wnioski:

- hałas jest zjawiskiem dźwiękowym

- hałas podlega ocenie subiektywnej.

Względność tej definicji wynika $\mathrm{z}$ tego, że ten sam dźwięk, w takich samych warunkach, może być dla jednych dźwiękiem pożądanym, a dla innych dźwiękiem niepożądanym, czyli hałasem. Ucho ludzkie jest w stanie odbierać dźwięki o częstotliwościach zawartych w paśmie częstotliwości od $16 \mathrm{~Hz}$ do $16000 \mathrm{~Hz}$. Pasmo to nosi nazwe pasma słyszalnego. Hałas o niskiej częstotliwości, mniejszej od $16 \mathrm{~Hz}$, odbierany jest jako pojedyncze impulsy. Pasmo to nazywane jest infradźwiękowym. Natomiast hałas zawarty powyżej pasma słyszalnego nie wywołuje wrażenia słuchowego i jest pasmem ultradźwiękowym [2].

W środkach transportu każdy generowany dźwięk jest niepożądany z punktu widzenia podróżnych jak i operatora pojazdu (kierowcy, maszynisty, motorniczego). Współczesne pojazdy konstruowane są tak, aby zapewnić maksimum komfortu jazdy pasażerom oraz osobom obsługującym pojazd, w tym minimalnego poziomu hałasu. Hałas oddziałuje nie tylko na organ słuchu, ale także poprzez centralny układ nerwowy na inne organy. Nadmierny hałas wpływa negatywnie nie tylko na narząd słuchu, lecz również na ogólny stan zdrowia, stan psychiczny i emocjonalny oraz somatyczny. Powoduje brak poczucia bezpieczeństwa i niezależności, uniemożliwia porozumiewanie się $\mathrm{i}$ orientację $\mathrm{w}$ środowisku pracy i życia, a także znacząco pogarsza komfort pracy i wypoczynku. Im wyższy poziom dźwięku, tym skutki działania hałasu mogą być gorsze.

Tramwaje należą w wielu miastach do podstawowych środków transportu masowego. Duża częstotliwość ruchu tramwajów, szczególnie w godzinach szczytu, powoduje generowanie znacznego poziomu hałasu. Poziom hałasu tramwajów zależy od konstrukcji, stanu technicznego oraz sposobu posadowienia toru. $\mathrm{W}$ tabeli 1 przedstawiono poziom hałasu generowany przez poruszający się tramwaj w zależności od sposobu posadowienia torów. Jak wynika z przedstawionych danych, największy poziom hałasu generowany jest przez tramwaje poruszające się po szynach posadowionych wprost na betonie, a najmniejszy na szynach posadowionych na podkładach i płycie betonowej z izolacją sprężystą.

\section{Zależność poziomu halasu generowanego przez tramwaje $w$} zależności od sposobu posadowienia torów [3]

Tabela 1

\begin{tabular}{|c|l|c|}
\hline Lp. & \multicolumn{1}{|c|}{ Sposób posadowienia torów } & $\begin{array}{c}\text { Poziom } \\
\text { hałasu [dB] }\end{array}$ \\
\hline 1. & Szyny wprost na betonie & $82 \div 85$ \\
\hline 2. & $\begin{array}{l}\text { Szyny na podkładach drewnianych, } \\
\text { na żwirze, wypełnione brukowcem }\end{array}$ & 78 \\
\hline 3. & Szyny zalane asfaltem & 73 \\
\hline 4. & $\begin{array}{l}\text { Szyny na podkładach posadowio- } \\
\text { nych na płycie betonowej z izolacją } \\
\text { sprężystą }\end{array}$ & 60 \\
\hline
\end{tabular}

Celem artykułu jest analiza oraz ocena poziomu hałasu panującego wewnątrz tramwajów na postoju oraz podczas jazdy. Badania poziomu hałasu przeprowadzono podczas wykonywania przez tramwaje normalnej pracy przewozowej (z pasażerami) w porze dziennej. Pomiarami objęto trzy typy tramwajów eksploatowanych w MPK Poznań: 
- $105 \mathrm{~N} / 105 \mathrm{Na}-36$ sztuk

- Duewag GT6/GT8 - 22 sztuki

- Tatra RT6-N1 - 4 sztuki.

\section{Normy i przepisy krajowe związane $z$ hałasem $w$} transporcie

Przeprowadzona analiza norm i przepisów krajowych, związanych $\mathrm{z}$ hałasem $\mathrm{w}$ transporcie pod kątem ich zastosowania do oceny poziomu hałasu wewnątrz tramwajów, wykazała brak w Polsce odpowiedniej normy. Istnieje tylko Rozporządzenie Ministra Transportu i Gospodarki Morskiej z dnia 17 września 1999 r [5], które zawiera ogólne wymagania dotyczące poziomu hałasu zewnętrznego tramwajów na postoju oraz podczas jazdy. Rozdział pierwszy zawiera następujące wytyczne odnośnie do poziomu hałasu: „Wagon powinien być tak zbudowany i utrzymany, aby poziom hałasu nie przekraczał:

- przy stałej prędkości $50 \mathrm{~km} / \mathrm{h}$, na torowisku wydzielonym z podkładami żelbetonowymi na thuczniu, na zewnątrz wagonu, w odległości 7,5 m od osi toru i na wysokości $1,60 \mathrm{~m}$ od główki szyny - $88 \mathrm{~dB}(\mathrm{~A})$

- na postoju, w odległości 3,0 m od dowolnej ściany wagonu, na wysokości $1,60 \mathrm{~m}$ od główki-70 dB(A); nie dotyczy to wagonów wyprodukowanych przed dniem 1 stycznia 1999 r."

$\mathrm{W}$ takiej sytuacji do oceny zmierzonego poziomu hałasu wewnątrz tramwajów eksploatowanych w MPK Poznań, wykorzystano trzy obowiązujące polskie normy:

1.PN-92/K-11000 [6]. Norma zawiera ogólne wymagania i badania dotyczące parametrów akustycznych hałasu powstającego wewnątrz pojazdów trakcyjnych, wagonów osobowych i wagonów typu osobowego (bagażowe, pocztowe, restauracyjne, sypialne, służbowe itp.) oraz hałasu emitowanego do otoczenia przez ten tabor. Norma nie obejmuje dopuszczalnych wartości hałasu infradźwiękowego i ultradźwiękowego $\mathrm{w}$ wagonach osobowych, typu osobowego oraz w przedziałach pasażerskich pojazdów trakcyjnych.

Dopuszczalne poziomy hałasu wewnątrz pojazdów szynowych w czasie jazdy wynoszą:

- $78 \mathrm{~dB}$ na stanowisku maszynisty i pomocnika maszynisty pojazdu trakcyjnego

- $70 \mathrm{~dB} \mathrm{w}$ pomieszczeniach pojazdów trakcyjnych i wagonów osobowych przewidzianych do przewozów pasażerów i kursowania $\mathrm{w}$ pociągach podmiejskich i lokalnych
- $68 \mathrm{~dB}$ w przedziałach 2 klasy wagonów osobowych przewidzianych do kursowania $\mathrm{W}$ pociagach dalekobieżnych oraz w przedziałach służbowych wagonów pocztowych, bagażowych i restauracyjnych

- $65 \mathrm{~dB}$ w przedziałach 1 klasy wagonów osobowych przewidzianych do kursowania $\mathrm{w}$ pociagach dalekobieżnych, wagonach sypialnych i salonowych.

Wewnątrz pojazdów szynowych na postoju (bez pasażerów):

- $55 \mathrm{~dB}$ w przypadku hałasu powodowanego przez urządzenia wentylacyjnoogrzewcze w wagonach osobowych 1 klasy, sypialnych, z miejscami do leżenia, restauracyjnych i salonowych

- $60 \mathrm{~dB}$ w przypadku hałasu powodowanego przez urządzenia wentylacyjnoogrzewcze w wagonach osobowych 2 klasy i pozostałych pojazdach, w których znajdują się pomieszczenia dla pasażerów.

2. PN-90/S-04052 [7]. Norma zawiera ogólne wymagania i badania dotyczące poziomu hałasu wewnątrz samochodów osobowych, ciężarowych i autobusów. Może ona być stosowana w kwalifikacyjnych, homologacyjnych i okresowych badaniach samochodów. Dopuszczalne poziomy hałasu wewnątrz pojazdów samochodowych podczas jazdy na drodze twardej, prostej, równej bez pofałdowań, o nawierzchni asfaltowej przewidzianych do wprowadzenia po roku 1994 wynoszą:

- 79 dB dla samochodów osobowych

- $80 \mathrm{~dB}$ dla samochodów ciężarowych, długich z miejscami do leżenia, przewozów międzynarodowych, autobusów z wyjątkiem miejskich

- $82 \mathrm{~dB}$ dla samochodów ciężarowych i autobusów miejskich.

3. PN-N-01307 [8]. Norma zawiera dopuszczalne wartości hałasu w środowisku pracy ze względu na ochronę słuchu i możliwość realizacji przez pracownika jego podstawowych zadań oraz wymagania dotyczące wykorzystywania pomiarów. Norma dotyczy hałasu ustalonego i nieustalonego z wyłączeniem hałasu infradźwiękowego i ultradźwiękowego. Dopuszczalne poziomy hałasu na stanowisku pracy wynoszą:

- $75 \mathrm{~dB}$ w kabinach bezpośredniego sterowania, w laboratoriach ze źródłami hałasu, $\mathrm{w}$ pomieszczeniach $\mathrm{z}$ maszynami liczaccymi, maszynami do pisania i 
innych pomieszczeniach o podobnym przeznaczeniu

- $65 \mathrm{~dB}$ w kabinach dyspozytorskich, obserwacyjnych i zdalnego sterowania, w pomieszczeniach do wykonywania prac precyzyjnych i w innych pomieszczeniach o podobnym przeznaczeniu

- $55 \mathrm{~dB} \mathrm{w}$ pomieszczeniach administracyjnych, biur projektowych, do prac teoretycznych, opracowania danych i innych o podobnym przeznaczeniu.

\section{Charakterystyka badanych tramwajów}

\subsection{Tramwaj typu $105 \mathrm{~N} / 105 \mathrm{Na}$}

Jest to najpopularniejszy tramwaj eksploatowany obecnie w MPK Poznań i również w innych miastach. Pojedynczy wagon posiada stalową konstrukcję pudła. Zasadniczym elementem konstrukcji jest belka grzbietowa, dwie poprzecznice oraz elementy tworzace szkielet pudła. W wagonie zastosowano duże okna oraz mniejsze, służące jako wywietrzniki. Tramwaj wyposażony jest w klapy wentylacyjne w ilości 5 sztuk, które miały poprawić wymianę powietrza $\mathrm{z}$ otoczeniem. Cztery pary drzwi rozmieszczone są w taki sposób, że jedna para jest na przedzie i jedna na tyle wagonu oraz dwie pary obok siebie w środku, gdzie występuje największy ruch pasażerów. Tramwaj wyposażony jest $\mathrm{w}$ cztery silniki o mocy $41,5 \mathrm{~kW}$ każdy. Hamowanie jest elektrodynamiczne oraz za pomocą hamulców szczękowo-bębnowych i hamulca szynowego.

Wagon posiada 20 miejsc siedzących i 105 stojących. Długość wagonu wynosi $13500 \mathrm{~mm}$, szerokość $2400 \mathrm{~mm}$, wysokość bez pantografu $3600 \mathrm{~mm}$. Rozstaw osi w wózku napędnym wynosi $1900 \mathrm{~mm}$. Masa całkowita wagonu wynosi $16800 \mathrm{~kg}$.

\subsection{Tramwaj typu Duewag GT6/GT8}

Sa to tramwaje pozyskane z Niemiec i Holandii. Ich produkcję rozpoczęto $\mathrm{w}$ drugiej połowie lat pięćdziesiątych XX wieku w RFN, Holandii i Włoszech. Pierwsze tramwaje były produkowane jako 6-osiowe GT6 a następne jako 8-osiowe GT8. Tramwaje dwukierunkowe posiadaja prostą przednią szybę natomiast jednokierunkowe wycięcie $\mathrm{z}$ przodu pudła. Tramwaje były wykonywane w różnych wersjach szerokości pudła oraz niewielkich różnicach długości. Prędkość maksymalna od 60 do $70 \mathrm{~km} / \mathrm{h}$. W wagonach tych napędzany jest tylko przedni i ostatni wózek. Tramwaje te wyróżniają się cichym i spokojnym biegiem dzięki zastosowaniu przetwornicy statycznej i wkładek gumowych w wózkach napędowych.

Tramwaj GT6 posiada 45 miejsc siedzących i 126 stojących. Długość pojazdu wynosi $19095 \mathrm{~mm}$, wysokość z opuszczonym pantografem $3200 \mathrm{~mm}$. Rozstaw osi w wózku $1800 \mathrm{~mm}$ a masa całkowita
$20200 \mathrm{~kg}$. Tramwaj GT8 posiada 64 miejsca siedzące i 198 stojących. Długość pojazdu wynosi $25647 \mathrm{~mm}$, wysokość z opuszczonym pantografem $3200 \mathrm{~mm}$. Rozstaw osi w wózku $1800 \mathrm{~mm}$ a masa całkowita pojazdu $26000 \mathrm{~kg}$

\subsection{Tramwaj typu Tatra RT6-N1}

Tramwaj Tatra RT6-N1 jest niskopodłogowym tramwajem nowej generacji, wyprodukowanym przez czeskie zakłady ČKD. Serię tramwajów dla poznańskiego MPK wykonano w Fabryce Pojazdów Szynowych HCP Poznań przy współpracy z ČKD. Pojazd składa się z trzech członów, połączonych przegubowo. Dwa skrajne człony umieszczone są na wózkach napędowych, a człon środkowy na jednym wózku tocznym. Tatra wyposażona jest $\mathrm{w}$ dwa silniki o mocy $102 \mathrm{~kW}$ każdy, połączone wałami przegubowymi $\mathrm{z}$ dwustopniową przekładnią napędową i przekładnią czołową. Zawieszenie, dzięki któremu osiagnięto poprawę parametrów jezdnych przy różnych obciążeniach i różnie zużytych kołach, automatycznie utrzymuje stałą wysokość progu wejściowego. W skład zawieszenia wchodzą: poduszki pneumatyczne, gumowe ograniczniki i amortyzatory hydrauliczne. Wózki napędowe wyposażone są w trzy rodzaje hamulców: silnikowe hamulce elektrodynamiczne, hamulce mechaniczne tarczowe ze sterowaniem hydraulicznym i hamulce elektromagnetyczne szynowe.

Tramwaj posiada 46 miejsc siedzących i 169 stojących. Długość pojazdu wynosi $26280 \mathrm{~mm}$, szerokość $2440 \mathrm{~mm}$, wysokość z opuszczonym pantografem $3200 \mathrm{~mm}$. Rozstaw osi w wózku napędnym wynosi $1900 \mathrm{~mm}$ i tocznym $1800 \mathrm{~mm}$. Masa całkowita pojazdu $32850 \mathrm{~kg}$.

\section{Punkty pomiaru hałasu i metodyka badań}

Punkty pomiaru hałasu $\mathrm{w}$ tramwajach podczas jazdy i postoju rozmieszczono wg zaleceń normy PN90/S-04052 [7], przyjmując rodzaj samochodu mogącego przewozić stojących pasażerów. Do badań wybrano łącznie 62 tramwaje trzech typów: 105N/ $105 \mathrm{Na}$ - 36 sztuk, Tatra RT6 - 4 sztuki i GT6/GT8D 22 sztuki. W każdym z tramwajów wybrano po dwa punkty pomiarowe: jeden z przodu pojazdu i drugi w środku tramwaju. Mikrofon umieszczono na wysokości $700 \mathrm{~mm}$ nad powierzchnią siedzenia w płaszczyźnie symetrii siedzenia, natomiast w środku tramwaju mikrofon umieszczony był na wysokości $1600 \mathrm{~mm}$ nad powierzchnia podłogi. Na rys. 1 przedstawiono lokalizację punktów pomiarowych na przykładzie tramwaju Tatra RT6-N1. We wszystkich badanych tramwajach lokalizacja punktów pomiarowych była taka sama.

Wszystkie pomiary hałasu wykonano w dni powszednie od $7 \div 16$ maja $2003 \mathrm{r}$ od godziny $8^{00}$ do godziny $12^{00}$. Pomiary hałasu $\mathrm{w}$ punktach pomiarowych przedstawionych na rys. 1 realizowano podczas 

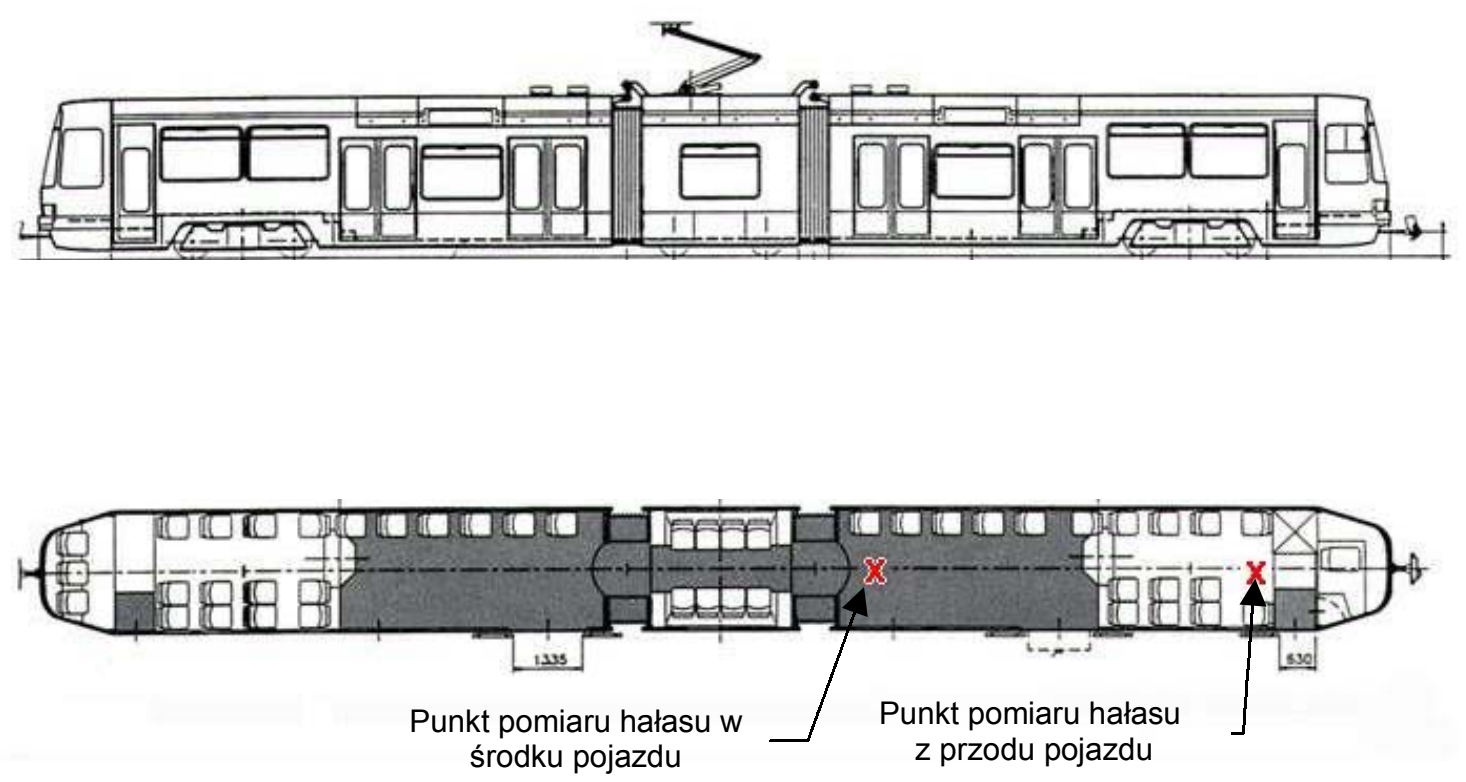

Rys. 1. Tramwaj Tatra z zaznaczonymi punktami pomiarowymi [4]

postoju tramwaju na pętli końcowej oraz w czasie jazdy $\mathrm{z}$ różnymi prędkościami, po różnych konstrukcjach torów. Podczas pomiaru na postoju tramwaj był bez pasażerów, natomiast podczas jazdy pomiary hałasu odbywały się w obecności pasażerów. W trakcie wykonywania pomiarów na postoju były włączone tylko wentylatory silników trakcyjnych, wszystkie okna i drzwi tramwajów były pozamykane.

Dla każdego typu tramwajów obliczono średnią wartość równoważnego poziomu dźwięku dla punktów umieszczonych $\mathrm{w}$ środku i $\mathrm{z}$ przodu pojazdu, zgodnie z zależnością wskazaną w normie PN-81/N01306 [9]:

$$
L_{\text {Aeq }}=10 \log \left[\frac{1}{n} \sum_{i=1}^{n} 10^{0,1 \cdot L_{i}}\right]
$$

gdzie:

$n$ - liczba pomiarów

$L_{i}$ - zmierzony równoważny poziom dźwięku w [dB].

Wszystkie pomiary wykonano całkującym miernikiem poziomu dźwięku typu 2238 Mediator $^{\mathrm{TM}}$ firmy Brüel \& Kjær. W ramach pojedynczego pomiaru rejestrowano następujące parametry sygnału akustycznego: równoważny poziom dźwięku $L_{A e q}$ i maksymalny poziom dźwięku $L_{A \max }$, przyjmując ustawienia parametrów miernika: charakterystykę korekcyjną A i stałą czasową FAST.

\section{Wyniki badań}

Pomiary hałasu wewnątrz tramwajów przeprowadzono dla 62 tramwajów trzech typów: $105 \mathrm{~N} / 105 \mathrm{Na}$, Duewag GT6/GT8D i Tatra RT6 podczas postoju oraz podczas jazdy z różnymi prędkościami na różnych torowiskach miasta Poznania. Przedstawione wyniki pomiarów zawierają średnie wartości równoważnego poziomu dźwięku wewnątrz tramwajów. Na rys. 2 przedstawiono wartości poziomu równoważnego hałasu $L_{A e q}$ wewnątrz poszczególnych typów tramwajów podczas postoju.

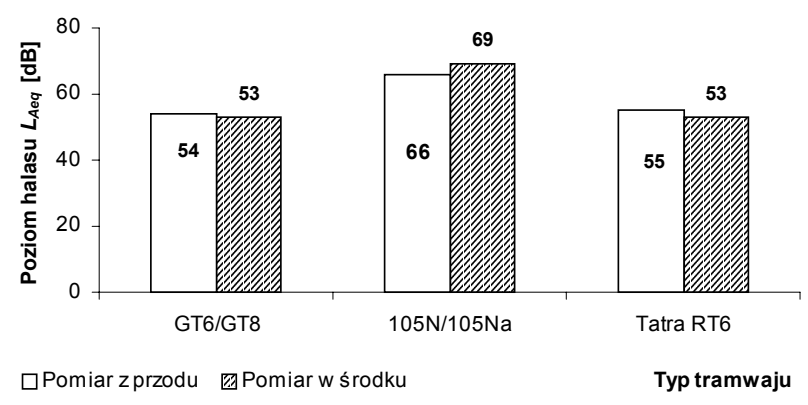

Rys. 2. Wartości poziomu hałasu w dB tramwajów podczas postoju

Przeprowadzone pomiary na postoju wykazały, że najwyższy poziom równoważnego poziomu dźwięku występował w tramwajach typu $105 \mathrm{~N} / 105 \mathrm{Na}$. W tramwajach typu Tatra RT6 oraz Duewag GT6/GT8D zmierzone równoważne poziomy dźwięku zarówno z przodu jak i w środku wagonów nie przekroczyły $56 \mathrm{~dB}$. Przyjmując według PN-92/K-11000 [6] dopuszczalny poziom hałasu powodowany przez urządzenia wentylacyjno-grzewcze podczas postoju w wagonach osobowych 2 klasy i pozostałych pojazdach, w których znajdują się pomieszczenia dla pasażerów jako $60 \mathrm{~dB}$ można stwierdzić, że dopuszczalny poziom hałasu podczas postoju jest przekroczony tylko w tramwajach typu $105 \mathrm{~N} / 105 \mathrm{Na}$. W pozostałych tramwajach poziom ten nie jest przekroczony.

$\mathrm{W}$ tabeli 2 oraz na rys. 3 przedstawiono wyniki pomiarów hałasu podczas jazdy tramwaju $105 \mathrm{~N} / 105 \mathrm{Na}$ z różnymi prędkościami. 
Wartości poziomu hałasu w dB wewnątrz tramwajów typu 105N/105Na podczas jazdy

Tabela 2

\begin{tabular}{|l|c|c|c|c|c|c|c|c|}
\hline Prędkość $[\mathrm{km} / \mathrm{h}]$ & $\mathbf{1 0}$ & $\mathbf{1 5}$ & $\mathbf{2 0}$ & $\mathbf{2 5}$ & $\mathbf{3 0}$ & $\mathbf{3 5}$ & $\mathbf{4 0}$ & $\mathbf{4 5}$ \\
\hline Pomiar z przodu tramwaju & 70.0 & 70,3 & 71,0 & 71,6 & 72,3 & 74,0 & 75,4 & 80,8 \\
\hline Pomiar w środku tramwaju & 70,2 & 70,8 & 71,5 & 73,0 & 74,1 & 75,0 & 76,2 & 82,1 \\
\hline
\end{tabular}

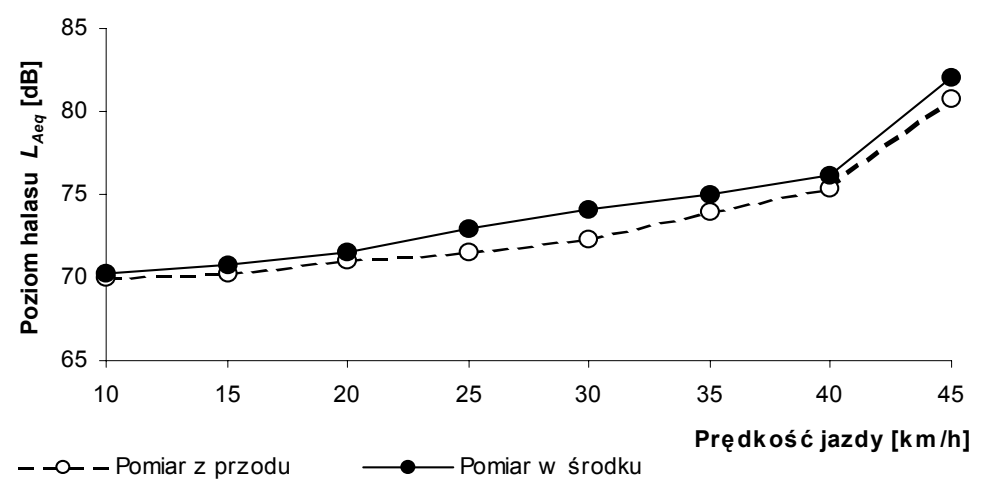

Rys. 3. Zmiany wartości poziomu hałasu tramwaju typu $105 \mathrm{~N} / 105 \mathrm{Na}$ w funkcji prędkości jazdy

Wartości poziomu hałasu w dB wewnątrz tramwajów typu Duewag GT6/GT8D podczas jazdy

Tabela 3

\begin{tabular}{|l|c|c|c|c|c|c|c|c|}
\hline Prędkość $[\mathrm{km} / \mathrm{h}]$ & $\mathbf{1 0}$ & $\mathbf{1 5}$ & $\mathbf{2 0}$ & $\mathbf{2 5}$ & $\mathbf{3 0}$ & $\mathbf{3 5}$ & $\mathbf{4 0}$ & $\mathbf{4 5}$ \\
\hline Pomiar z przodu tramwaju & 68.0 & 69,0 & 72,0 & 73,2 & 75,4 & 78,9 & 78,9 & 80,8 \\
\hline Pomiar w środku tramwaju & 68,5 & 69,7 & 74,0 & 74,5 & 76,0 & 80,7 & 79,3 & 82,1 \\
\hline
\end{tabular}

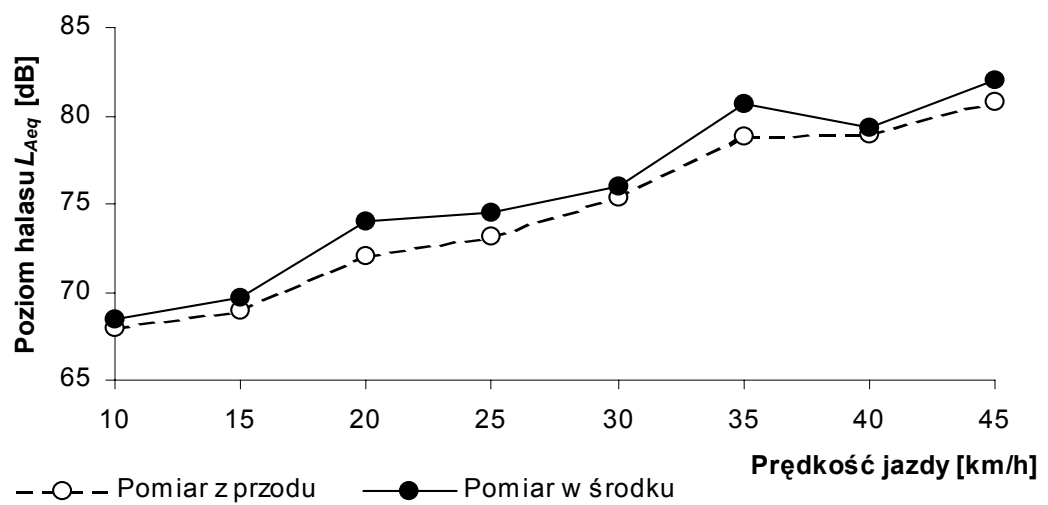

Rys. 4. Zmiany wartości poziomu hałasu tramwaju typu GT6/GT8 w funkcji prędkości jazdy

Dla otrzymanych wyników pomiarów hałasu wyznaczono modele regresyjne opisujące poziom hałasu w funkcji prędkości jazdy tramwajów. Jako kryterium wyboru postaci funkcji opisującej ten związek zastosowano współczynnik determinacji $\mathrm{R}^{2}$. Do wyznaczenia współczynników regresji równań wykorzystano aplikację Microsoft Excel.

Wyznaczone modele opisujące związek pomiędzy prędkością jazdy tramwaju a poziomem równoważnym hałasu $L_{A e q}$ pozwalają określać (oszacować) poziom hałasu poszczególnych tramwajów dla różnych prędkości jazdy.

Dla tramwaju typu $105 \mathrm{~N} / 105 \mathrm{Na}$, modele te mają postać:

- pomiary z przodu tramwaju

$$
L_{\text {Aeq }}=0,2793 v^{2}-1,1913 v+71,406
$$

- pomiary w środku tramwaju

$$
L_{\text {Aeq }}=0,2265 v^{2}-0,5908 v+70,994
$$

gdzie:

$v$ - prędkość jazdy $\mathrm{w}[\mathrm{km} / \mathrm{h}]$.

Współczynniki determinacji wynoszą odpowiednio $\mathrm{R}^{2}=0,96 \quad \mathrm{i}$ $\mathrm{R}^{2}=0,94$.

W tabeli 3 oraz na rys. 4 przedstawiono wyniki pomiarów hałasu podczas jazdy tramwaju Duewag GT6/GT8D z różnymi prędkościami.

Dla tramwaju typu Duewag GT6/GT8D, modele regresyjne opisujące poziom hałasu w funkcji prędkości jazdy mają postać:

- pomiary z przodu tramwaju

$$
L_{\text {Aeq }}=1,9246 v+65,857
$$

- pomiary w środku tramwaju

$$
L_{\text {Aeq }}=1,9616 v+66,773
$$

Współczynniki determinacji wynoszą odpowiednio $\mathrm{R}^{2}=0,98 \quad \mathrm{i}$ $\mathrm{R}^{2}=0,94$.

W tabeli 4 oraz na rys. 5 przedstawiono wyniki pomiarów hałasu podczas jazdy tramwaju Tatra RT6 z różnymi prędkościami.

Dla tramwaju typu Tatra RT6, modele regresyjne opisujące poziom hałasu $\mathrm{w}$ funkcji prędkości jazdy mają postać:

- pomiary z przodu tramwaju

$$
L_{\text {Aeq }}=1,8786 v+61,246
$$

- pomiary w środku tramwaju

$$
L_{\text {Aeq }}=1,6988 v+61,143
$$

Współczynniki determinacji wynoszą odpowiednio $\mathrm{R}^{2}=0,96 \quad \mathrm{i}$ $\mathrm{R}^{2}=0,93$. 
Wartości poziomu hałasu w dB wewnątrz tramwajów typu Tatra RT6 podczas jazdy

Tabela 4

\begin{tabular}{|l|c|c|c|c|c|c|c|c|}
\hline Prędkość $[\mathrm{km} / \mathrm{h}]$ & $\mathbf{1 0}$ & $\mathbf{1 5}$ & $\mathbf{2 0}$ & $\mathbf{2 5}$ & $\mathbf{3 0}$ & $\mathbf{3 5}$ & $\mathbf{4 0}$ & $\mathbf{4 5}$ \\
\hline Pomiar z przodu tramwaju & 64,5 & 65,0 & 65,8 & 68,0 & 70,0 & 72,2 & 75,8 & 76,3 \\
\hline Pomiar w środku tramwaju & 64,3 & 64,8 & 65,3 & 66,9 & 68,0 & 71,7 & 74,3 & 75,0 \\
\hline
\end{tabular}

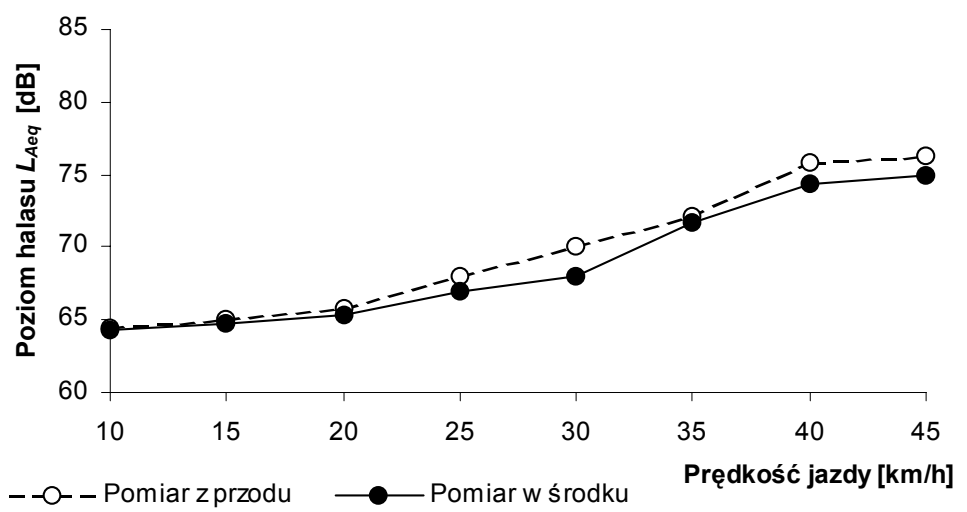

Rys. 5. Zmiany wartości poziomu hałasu tramwaju Tatra RT6 w funkcji prędkości jazdy

Przyjmując do oceny dopuszczalny poziom hałasu $70 \mathrm{~dB}$ wewnątrz tramwajów podczas jazdy wg PN92/K-11000 [6] (w pomieszczeniach pojazdów trakcyjnych i wagonów osobowych przewidzianych do przewozów pasażerów i kursowania w pociagach podmiejskich i lokalnych) można stwierdzić, że poziom ten dla prędkości $45 \mathrm{~km} / \mathrm{h}$ jest przekroczony przez wszystkie badane typy tramwajów (tabele 2, 3 i 4) przy czym najwyższy poziom hałasu występuje w tramwajach typu $105 \mathrm{~N} / 105 \mathrm{Na}$. Tramwaje te już przy prędkości jazdy $10 \mathrm{~km} / \mathrm{h}$ przekraczają dopuszczalny równoważny poziom dźwięku. W tramwajach typu Duewag GT6/GT8D dopuszczalny poziom hałasu przekroczony jest przy prędkości około $20 \mathrm{~km} / \mathrm{h}$ a w tramwajach Tatra RT6 dopiero po przekroczeniu prędkości $30 \mathrm{~km} / \mathrm{h}$.

Jeżeli przyjąć dopuszczalny poziom hałasu $78 \mathrm{~dB}$ na stanowisku maszynisty wg PN-92/K-11000 [6] oraz dopuszczalny poziom hałasu na stanowisku pracy $75 \mathrm{~dB}$ wg PN-N-01307 [8], to poziom hałasu $\mathrm{z}$ przodu tramwaju jest przekroczony przez tramwaje typu $105 \mathrm{~N} / 105 \mathrm{Na}$ oraz Duewag GT6/GT8D. W tramwajach typu Tatra RT6 przy prędkości jazdy $45 \mathrm{~km} / \mathrm{h}$ równoważny poziom dźwięku występuje na granicy poziomu dopuszczalnego $75 \mathrm{~dB}$ wg PN-N01307 [8]. Można zatem stwierdzić, że tramwaje typu Tatra spełniają dopuszczalne poziomy określone $\mathrm{w}$ normach. Przyczyną tego może być $\mathrm{m}$. in. fakt, że tramwaje typu Tatra RT6 jeżdżą głównie po trasie szybkiego tramwaju (PST), gdzie torowisko jest nowe i niezużyte.

\section{Podsumowanie}

W artykule przedstawiono wyniki pomiarów hałasu wewnątrz tramwaju dla trzech typów: $105 \mathrm{~N} /$ 105Na, Duewag GT6/GT8D i Tatra RT6 podczas postoju oraz jazdy. Pomiarom hałasu poddano ogółem
62 tramwaje w tym: $105 \mathrm{~N} / 105 \mathrm{Na}-36$ sztuk, Tatra RT6 - 4 sztuki, Duewag GT6/ GT8D - 22 sztuki. Pomiary podczas jazdy przeprowadzono bez wyróżnienia konstrukcji torowiska, stanu technicznego tramwajów oraz stanu środowiska, w którym odbywała się jazda (różne natężenie ruchu pojazdów samochodowych itp.). Zatem otrzymane wyniki dotyczą uśrednionych warunków jazdy tramwajów. Tym niemniej wyniki pozwalają na ogólną ocenę poziomu hałasu, panującego wewnątrz tramwajów podczas jazdy.

Na podstawie przeprowadzonych pomiarów można sformułować następujące wnioski:

- dopuszczalny poziom hałasu podczas postoju przekroczony jest tylko w tramwajach typu $105 \mathrm{~N} / 105 \mathrm{Na}$ (rys. 2)

- w tramwajach typu $105 \mathrm{~N} / 105 \mathrm{Na}$ podczas jazdy dopuszczalny poziom hałasu jest przekroczony już przy prędkości $10 \mathrm{~km} / \mathrm{h}$

- w tramwajach typu Duewag GT6/ GT8D dopuszczalny poziom hałasu jest przekroczony przy prędkości około $20 \mathrm{~km} / \mathrm{h}$

- w tramwajach Tatra RT6 dopuszczalny poziom hałasu przekroczony jest przy prędkości $30 \mathrm{~km} / \mathrm{h}$.

\section{Literatura}

[1] Lipowczan A.: Podstawy pomiarów hałasu. Wydawnictwo GIG i Ligi Walki z Hałasem, Katowice 1987.

[2] Puzyna C.: Ochrona środowiska pracy przed hałasem. Tom 2, WNT, Warszawa 1982 r.

[3] Kubalski J.: Tory tramwajowe, WKE, Warszawa $1978 r$.

[4] Rutowski K.: Ocena poziomu hałasu wewnętrznego tramwajów eksploatowanych w MPK Poznań. Praca dyplomowa. Politechnika Poznańska 2003.

[5] Dziennik Ustaw Nr 88 z 1999 roku poz. 993 „,Rozporzqdzenie Ministra Transportu i Gospodarki Morskiej z dnia 17 września 1999 roku w sprawie warunków technicznych tramwajów $i$ trolejbusów oraz zakresu ich niezbędnego wyposażenia”.

[6] Norma PN-92/K-11000 „Tabor kolejowy. Hałas. Ogólne wymagania i badania".

[7] Norma PN-90/S-04052 „Samochody. Dopuszczalny poziom hałasu wewnętrz pojazdu. Wymagania i badania".

[8] Norma PN-N-01307 „Hałas. Dopuszczalne wartości poziomu dźwięku na stanowiskach pracy. Wymagania dotyczqce wykonywania pomiarów”. Wyd.1994 r.

[9] Norma PN-81/N-01306 „Hałas. Metody pomiaru. Wymagania ogólne”. 